\title{
An Empirical Study of Leadership and Non-Financial Business Performance of Brewery Industry in Nigeria
}

\author{
Abayomi Abidakun \\ College of Management and Technology, Walden University, Minnesota
}

\begin{abstract}
This study examined leadership and non-financial performance at the brewery industry in Nigeria. The study used cross-sectional survey research design to survey 736 senior and junior employees of the company. The Multifactor Leadership Questionnaire, job satisfaction scale, three-component commitment scale, and turnover intention scale was adopted to collect data. The participants were recruited through Survey Monkey. Stratified sampling was adopted to ensure representative sample. Three hypotheses were tested using Pearson's correlation and hierarchical regression analysis. Findings of the study revealed that the three leadership styles are positively correlated with job satisfaction, and employee commitment. Also the three leadership style are negatively and statistical correlated with turnover intention. Cadre of employee (senior or junior employee) is a significant predictor of employee job satisfaction and commitment. Both age and years of experience on the job are significant predictor of employee turnover intention. On the basis of the aforementioned findings, this study concluded that the adoption of effective leadership style is critical to job satisfaction, employee commitment and turnover intention. It is recommended that leaders should adopt effective leadership style to foster employee job satisfaction and commitment with a view of lessen turnover intention.

Keywords: transformational leadership style, transactional leadership style, laisses-faire leadership style, job satisfaction, employee commitment, turnover intention.
\end{abstract}

\section{INTRODUCTION}

The growth potential of the brewery industry in Africa and Nigeria in particular, is increasingly growing and encouraging multinational companies to seek consolidation opportunities through mergers and acquisition purposes to improve their market share and competitiveness (Meristem Securities, 2014; Haukur, 2017). To manage complications connected to consolidation drive, there is need for strong leadership to drive the change process and performance improvement (Salleh \& Grunewald, 2013). The quest for improving business performance is one of the vital goals of every business organization (Rahim, Ofuani, \& Olonode, 2018). Consequently, there is need for effective leadership to sustain company performance in both short and long term (Babatunde, 2015). According to Mat (2008), the descriptions and meaning of leadership are evolving and researchers are striving to improve understanding and recognition of leadership as a fundamental basis of firm success and business sustainability. Leadership is extensively studied in management literature and generally defined as the capability to influence subordinates towards a desired goal (Robbins \& Judge, 2017). There are three major leadership styles, including transactional, laissez-faire, and transformational leadership, and each of these leadership styles have been reported to influence dispositional and organizational outcomes such as job satisfaction, commitment and turnover intention. Desired employees' behavior and work performance can only occur if the leaders are able to manage them productively (Mosadeghrad, 2003). Many scholars have documented that employee job satisfaction and commitment rely mostly on the leadership style to enhance the performance of both employee and the entire organization (Tnay, Othman, Siong, \& Omar, 2013).

According to Wang, Wang, Xu, and Ji (2014), there is a direct link employee performance and leadership styles. Employee job performance can be viewed as the value that an individual brings to the company (Motowidlo \& Kell, 2012). In this competitive business environment, leadership is needed to enhance job satisfaction and poor leadership has been documented as one of the major outcomes of poor employee and organizational performance. According to Haque, Faizan and Cockrill (2017), satisfied employee is more efficient and dexterous in performing his or her work. Academics have documented that employee commitment and leadership styles are fundamental influences that determine organizational success or failure (Trottier, Van Wart, \& Wang, 2008). According to Robbins (2006), employee commitment evaluates the degree to which employee recognizes and aligns with the goals/ hopes of the organization and maintain the status as the group member. According to Yasir, Imran, Irshad, Mohamad, and Khan (2016), the growing interest in leadership is a result of the conviction that if employees are properly managed, it will lead to improve job satisfaction, and employee commitment which may lessen turnover intention. Withdrawal of employees 


\section{An Empirical Study of Leadership and Non-Financial Business Performance of Brewery Industry in Nigeria}

mostly label as turnover intention could have a considerable negative consequence on organizational processes and outcomes. The consequences of employee turnover for business organizations are multidimensional and contain loss of employees who possess requisite competencies and, most important, knowledge that may be challenging to easily replace. Besides, high rate of attrition has serious consequences on firm's performance (Phuong, 2016).

\subsection{Statement of the Problem}

Changing business landscape and competitiveness have demanded the need for leadership effectiveness to enhance employee job satisfaction, commitment and turnover intention. Newhaul (2012) stated that only $50 \%$ to $60 \%$ of leaders in most organizations admitted being effective in demonstrating leadership competences to stimulate desired employee behavior to sustain performance improvement. Factors that increase employees' job satisfaction and commitment have become a huge challenge for businesses, necessitating the need for leadership to adopt the right and effectiveness leadership styles towards improving employees' job performance and commitment. According to Abayomi (2020), countless companies face challenges of high employee turnover, lack of job commitment, resulting to poor business performance. This has caused low productivity and difficulty in sustaining organizational performance. Therefore, adopting effective leadership styles provide basis for enhancing job performance, employee commitment and provide basis for reducing turnover intention. Leadership is one of the major influences that ensure the success of a company. Companies need skillful, competent and committed workers to accomplish desired goals. There have been a number of studies that have identified leadership conducts as vibrant element that determine employee job performance and commitment (Garg \& Ramjee, 2013; Dahie, Mohammed, \& Muhammed, 2017; Gcaza, Garande, \& Ezhezona, 2018). Similarly, scholars have confirmed the connection between leadership and employee turnover intention (Wang et al. 2014; Abayomi, 2020). According to Jing and Avery (2008), notwithstanding high conjectured between leadership-performance relationships documented by some academics, research outcomes are indecisive and making it challenging to deduce direct assessments between the two variables.

\subsection{Objective of the Study}

This study examined the association between leadership and non-financial performance of the brewery industry in Nigeria. The specific objectives are:

I. To investigate the relationship between leadership style and job satisfaction in the brewery industry in Nigeria.

II. To study the relationship between leadership style and employee commitment in the brewery industry in Nigeria.

III. To examine the relationship between leadership style and turnover intention in the brewery industry in Nigeria.

\section{LITERATURE REVIEW AND THEORETICAL FRAMEWORK}

\subsection{Leadership: Definition and Meaning}

The growing interest in leadership research by academics and business practitioners is because of its strategic importance in business, political, educational, and social establishments for the achievement of both short and long-term objectives. Literarily, leadership in the organizational context is related to the person who is recognized by the organization to coordinate the activities of the company. Leadership is a process of having outstanding influence on subordinates to accomplish predetermined goals (Burns, 2003). According to Fry (2003), leadership is a strategic practice of offering motivation by the leader to improve employee's potential for growth and development. Northouse (2016) defined leadership as a way of influencing subordinates to accomplish common objectives. Leadership styles are behaviors or practices that leaders use to promote accomplishment of extraordinary performance (Bass \& Avolio, 1994). Leadership literature is proliferated with many leadership styles, some of the major ones are: transformational, transactional and laissez-faire leadership styles. Transformational leadership style inspires employee to develop themselves and improve their competence towards accomplishment of desired goals. Transactional leaders demonstrate preference for beneficial and counteractive dealings to guarantee that employees achieve desired tasks (Bass \& Bass, 2008). Transactional leaders are not interested in relationship building with subordinates; instead, they desire exchange in term of work accomplishment and reward (Harms \& Crede, 2010). Laissez-faire leadership style is described by its physical presence but absence of real leadership practices and activities (Burns, 2003). Laisses-faire leadership style abstains from decisions or reluctance when needed (Bass \& Bass, 2008). Laissez-faire leadership style is characterized by the leader's non-feasible or lack of connection with the job activities (Goodnight, 2011).

\subsubsection{Leadership and Employee Job Satisfaction}

The notion of employee satisfaction is a phenomenon that has been widely studied by researchers (Spector, 2011). Job satisfaction has been conceptualized in many different ways in literature. Some viewed it as the level of happiness connected to employee work. Park and Deitz (2006) defined job satisfaction as the inner most accord of employees in connection to his or her job. Furnham, Eracleou, and Chamorro-Premuzic (2009) conceptualized job satisfaction as the extent to which employees are satisfied with their work. According to Eskildsen and Dahlgaard (2000), employee perception regarding leadership behavior and style is a predictor of job satisfaction. According to Burns (2003), rising job satisfaction in the workplace cannot be detached from the quality of leadership. Ni-Nengah, Wayan, and Nengah (2018) stated that leadership style has positive and considerable impact on job satisfaction. According to Shahzad and Khanzada (2018), transformational leadership positively influences job satisfaction and performance. Burns (2003) stated that the application of transformational leadership in any company significantly influence 


\section{An Empirical Study of Leadership and Non-Financial Business Performance of Brewery Industry in Nigeria}

job satisfaction of workers. Miles and Mangold (2002), said that job satisfaction is easier to accomplish by leaders who adopt transformational style because of effective interaction with employees. Northouse (2016) expressed similar position and confirmed that transformational leadership positively influences job satisfaction.

\subsubsection{Leadership and Employee Commitment}

Job commitment remains one of the most investigated phenomena in the literature of organizational behavior and management (Babatunde, 2015; Abdul, Veronica, \& Zubair, 2017). According to Sid (2018), employee commitment refers to the readiness to persist in a course of action over a given period of time. Allen and Mayer (1990) identified three dimensions of employee commitment: affective, continuance, and normative commitment. Employees with affective commitment maintain his or her employment with the organization because they enjoy working with the company (Vandenberghe, 2014). Continuance commitment is a propensity to engage in stable lines of activity based on the individual's perception of the 'costs' connected with halting the activity. Normative commitment refers to totality of internalized normative burdens in accomplishing organizational objectives (Fu, Bolander, \& Jones, 2009). Job commitment is larger for employees whose leaders solicit and encourage their participation in decision making process (Ugboro, 2006), who consider employees with utmost consideration (Shore \& Wayne, 1993), treat them with fairness (Brockner, Tyler, \& Schenider, 1992) and are supportive of subordinates (Allen \& Meyer, 1990). According to Yahchouchi (2009), leadership style was presumed to be more transformational than transactional and that both leadership styles exert positive association and influence on employees' job commitment. Raja and Palanichamy (2011) stated that transformational leadership style was more favored and more connected to employees' commitment than transactional leadership. Garg and Ramjee (2013) reported a weak positive significant association between transformational leadership and affective, normative, and continuance commitment.

\subsubsection{Leadership and Employee Turnover Intention}

Employee turnover intention is level of workforces that will quit an organization before the end of their employment contract (Loquercio, Hamersley, \& Emmens, 2006). Turnover intention is viewed as an antecedent of the actual behavior of leaving the company, and many scholars established a strong association between turnover intentions and actual turnover behavior (Lee, \& Ha-Brookshire, 2017). Turnover can be categorized as voluntary and involuntary. Employees who seek for higher opportunity in other company initiate voluntary turnover (Rahman \& Nas, 2013). Involuntary turnover, on the other hand, is due to the dismissal of employees by the company (Abbasi, Hollman, \& Hayes, 2008). According to Siew (2017), leadership styles exert strong association with turnover intention. Tse and Lam (2008) reported that both transformational and transactional leadership have a very strong influence on turnover intention. Long, Yusof, Kowang, and Heng (2014) reported negative non-significant relationship between turnover intentions and transactional and transformational leadership styles. Workforces under democratic leadership style are less likely to engage in turnover intentions due to the collaboration and inspiration from the leader. Siew (2017) documented significant association between transformational and transactional leadership style and turnover intention. Employees are more persuaded and motivated by leaders who demonstrate care and concern for them (Abayomi, 2020).

\subsection{Transformational Leadership Theory}

For several decades, transformational leadership theory has been recognized as a major approach in studying leadership styles (Northhouse, 2016). Transformational leadership theory originates from Burns in 1978 and later improvised by Bass in 1985. According to Kirkbride (2006), the inspiration and motivation of transformational leaders reassure subordinates towards greater job efficiency. Leaders that adopt a transformational leadership style inspire subordinates to be innovative and imaginative, thus, promoting learning approach to resolving complicated problems (Schepers, Wetzels, \& Ruyter, 2005). According to Mujkic, Sehic, Rahimic and Jusic (2014), transformational leadership demonstrates how the leader inspires and encourages other workers to bring out outstanding performance. Transformational leadership consists of four elements, namely charismatic, inspirational, intellectual stimulation, and individualized consideration. The concept of charismatic leadership style often labels as idealized influence described how leadership arises to manage complications (Burns, 2003). Inspirational motivation is level to which leader expresses disposition that is engaging and motivate employees (Burns, 2003). Intellectual stimulation describes how leader encourages employees towards accomplishment of tasks and desired performance standards (Bass \& Bass, 2008). Individualized consideration describes the extent to which the leader demonstrates concern and offers the needed climate for them to exploit their capability (Burns, 2003).

\subsection{Research Hypotheses}

This study addressed three research hypotheses in null forms.

Ho1: There is no statistical association between leadership style and job satisfaction in the brewery industry in Nigeria.

Ho2: There is no statistical association between leadership style and employee commitment in the brewery industry in Nigeria.

Ho3: There is no statistical association between leadership style and turnover intention in the brewery industry in Nigeria.

\section{METHODOLOGY}

The study adopted correlational research design to investigate the relationship among the phenomena under investigation. 


\section{An Empirical Study of Leadership and Non-Financial Business Performance of Brewery Industry in Nigeria}

\subsection{Population, Sample Size and Sampling Approach}

The target population for this study was managers on both senior and junior cadres at Nigerian Breweries Plc. The company has 736 managers (both senior and junior) spread across it headquarter, brewery plants and regional business units in Nigeria. To obtain the sample size, Yemane formula (1967) sample size formula was used. The study arrived at 400 sample size. Stratified random sampling was used to select participants.

\subsection{Measures and Instrumentation}

Four distinct instruments were adopted to measure variables investigated in this study. The Multifactor Leadership Questionnaire (MLQ) developed by Bass and Avolio (1994) was used to measure leadership styles, Job Satisfaction Survey developed by Spector (2011) was adopted to evaluate employees' job satisfaction, Employee Commitment Scale developed by Mayer and Allen (1991) was used to assess employees' commitment, and Employee Turnover Intention scale developed by Bothman and Roodnt (2013) was adopted to estimate employees' turnover intention. An online survey method, known as Survey Monkey was used to gather opinion concerning phenomena under investigation.

\subsection{Data and Statistical Analysis}

Responses gathered were analyzed using Statistical Package for Social Sciences (SPSS). Hypotheses were tested using Pearson correlation and hierarchical multiple regression analysis. All the assumptions for employing regression analysis were met satisfactorily.

\subsection{RESULTS AND DISCUSSIONS}

Table 1:Demographic Characteristics of Respondents

\begin{tabular}{lll}
\hline Variables & Frequency & Percentage (\%) \\
\hline Gender & 159 & 71.6 \\
Male & 63 & 28.4 \\
Female & & \\
Age Group & 28 & 5.6 \\
$26-25$ years & 187 & 37.2 \\
$36-45$ years & 138 & 27.4 \\
$46-55$ years & & \\
Years on the Job & 10 & 4.5 \\
Less than 1 year & 21 & 9.5 \\
$2-3$ years & 17 & 7.7 \\
$4-5$ years & 35 & 15.8 \\
6-7 years & 139 & 62.6 \\
8 years and above & & \\
Cadre of Employment & 164 & 73.9 \\
Junior manager & 58 & 26.1 \\
Senior manager & & \\
Educational Qualification & 5 & 2.3 \\
Diploma or equivalent & 89 & 40.1 \\
Bachelor's Degree or equivalent & 119 & 53.6 \\
M.Sc./MBA or equivalent & 1 & 0.5 \\
Doctorate Degree & 8 & 3.6 \\
Others &
\end{tabular}

Source: Field Survey, 2019

As shown in Table 1, participants were 222 employees at the Nigerian Breweries Plc. There were $159(71.6 \%)$ men and 63 (28.4\%) women. Regarding their age, 78 (35.1\%) were between 26 and 35 years old, 102 (45.9\%) were between 36 and 45 years and $42(18.9 \%)$ were between 46 and 55 years. Regarding years with current employer, 10 (4.5\%) were employed less than 1 year, $21(9.5 \%)$ were employed between 2 and 3 years, $17(7.7 \%)$ employed between 4 and 5 years, $35(15.8 \%)$ were employed between 6 and 7 years, and $139(17 \%)$ were employed between 8 years and above. As regard their cadre or position, $164(73.9 \%)$ were junior manager and $58(26.1 \%)$ were junior level manager. Concerning their educational level, $5(2.3 \%)$ were diploma holder or equivalent, $89(40.1 \%)$ were university graduates or equivalent, $119(53.6 \%)$ holds a Master's degree or equivalent, $1(0.5 \%)$ holds Doctorate degree. Content analysis of those that indicated "other" $8(3.6 \%)$ revealed that 6 of those participants hold postgraduate diploma, 1 hold diploma in Brewery and the remaining 1 holds professional qualification.

Ho1: There is no statistical association between leadership style and job satisfaction in the brewery industry in Nigeria 


\section{An Empirical Study of Leadership and Non-Financial Business Performance of Brewery Industry in Nigeria}

Table 2: Correlation Matrix of Leadership and Job satisfaction

\begin{tabular}{lllllll}
\hline & Mean & SD & 1 & 2 & 3 & 4 \\
\hline Transformational Leadership & 3.19 & .616 & 1 & & & \\
Transactional Leadership & 2.20 & .765 & $.269 * *$ & 1 & & \\
Laisses-faire Leadership & 1.29 & 1.406 & .077 & $.726^{* *}$ & 1 & \\
Employee satisfaction & 3.48 & .364 & .006 & $.165^{*}$ & $.192^{* *}$ & 1 \\
\hline
\end{tabular}

Source: Field Survey, 2019

Table 2 shows inter-correlations among the three leadership styles and employee satisfaction. As shown in Table 2, the mean values for the transactional and laisses-faire leadership styles are relatively low compare to transformational leadership style. Employee satisfaction is relatively higher. Specifically, the dimensions of leadership styles exhibited low to moderate positive relationship with one another. From Table 4, the relationship among leadership styles and employee satisfaction shows that, transformational leadership style and employee satisfaction $(\mathrm{r}=.006, \mathrm{p}>0.01)$, transactional leadership style and employee satisfaction $\left(r=.165^{*}, \mathrm{p}<0.01\right)$, and laisses-faire leadership style and employee satisfaction $\left(r=.192^{*}, \mathrm{p}<0.01\right)$. From the above results, transformational leadership exhibits low and non-significant relationship with employee job satisfaction. Both transactional and laissez-faire leadership styles exhibit low positive significant relationship with employee job satisfaction. Two steps hierarchical regression is then run.

Table 3: Results of the hierarchical multiple regression with step 1 (predictors predicting employee satisfaction, controlling for demographic variables)

\begin{tabular}{|c|c|c|c|c|c|c|}
\hline Source & B & $\mathrm{SE}$ & $\mathrm{B}$ & $\mathrm{T}$ & $\mathrm{P}$ & $\begin{array}{l}\text { Significant } \\
\text { predictor }\end{array}$ \\
\hline Gender & .028 & .053 & .034 & .528 & .598 & No \\
\hline Age & .026 & .036 & .051 & .715 & .475 & No \\
\hline Years of experience on the job & -.032 & .022 & -.107 & -1.473 & .142 & No \\
\hline Cadre of employee & .307 & .053 & .371 & 5.773 & .000 & Yes \\
\hline Educational qualification & .017 & .015 & .073 & 1.122 & .263 & No \\
\hline
\end{tabular}

Results for the first block of the hierarchical regression are presented in Table 3. The first step (block 1) of the hierarchical multiple regression revealed that among the demographic variables consisting gender, age, years of experience on the job, cadre of employee and educational qualification evaluated, only cadre of employee $(\beta=.371, t=5.773$ and $p<.001)$ is a significant predictor of employee job satisfaction, others are not a significant predictor of employee job satisfaction. The first model revealed the following statistics $\mathrm{F}(5,216)=7.166, \mathrm{p}=.000, \mathrm{R}=.377, \mathrm{R}^{2}=.142$ and adjusted $\mathrm{R}^{2}=.122$. Result for step 2 of the hierarchical multiple regression is presented in Table 4 . In the second step (block 2) of the hierarchical multiple regression that included all of the predictor variables revealed that the combination of the control variables and the three leadership styles do significantly predict employee satisfaction, $\mathrm{F}(3,213)=4.789$, $\mathrm{p}<.001$.

Table 4: Results of the hierarchical multiple regression with step 2 (control variables and predictors predicting employee satisfaction)

\begin{tabular}{|c|c|c|c|c|c|c|}
\hline Source & $\mathrm{B}$ & SE & $\mathrm{B}$ & $\mathrm{T}$ & $\mathrm{P}$ & $\begin{array}{l}\text { Significant } \\
\text { predictor }\end{array}$ \\
\hline Gender & .021 & .052 & .026 & .399 & .690 & No \\
\hline Age & .042 & .036 & .083 & 1.170 & .243 & No \\
\hline Years of experience on the job & -.029 & .022 & -.096 & -1.348 & .179 & No \\
\hline Cadre of employee & .411 & .065 & .497 & 6.325 & .000 & Yes \\
\hline Educational qualification & .020 & .015 & .087 & 1.344 & .180 & No \\
\hline Transformational leadership & -.154 & .045 & -.261 & -3.460 & .001 & Yes \\
\hline Transactional leadership & -.016 & .046 & -.034 & -.346 & .730 & No \\
\hline Laissez-faire leadership & .018 & .024 & .069 & .755 & .451 & No \\
\hline
\end{tabular}

From Table 4 above, the entire group of variables significantly predicted employee job satisfaction $\mathrm{F}(8,213)=6.510$, $\mathrm{p}<.001$, $\mathrm{R}=.443, \mathrm{R}^{2}=.196$, adjusted $\mathrm{R}^{2}=.166$. From the above statistics, the entire variables predicted $17 \%$ of employee job satisfaction. The coefficient of determination $\left(\mathrm{R}^{2}\right)$ indicated that $17 \%$ of the variation in employee satisfaction can be explained by leadership consisting of transformational, transactional and laissez-faire leadership styles. Finding of this study revealed that leadership predicts employee satisfaction. From the results of statistical analysis, hypothesis one which states that there is no statistical association between leadership and employee job satisfaction in the brewery industry in Nigeria is not supported. Findings of this 


\section{An Empirical Study of Leadership and Non-Financial Business Performance of Brewery Industry in Nigeria}

study lend acceptance to the view expressed by Eskildsen and Dahlgaard (2000) and Burns (2003) that growing level of employee satisfaction in the workplace is strongly connected to leadership.

Ho2: There is no statistical association between leadership style and employee commitment in the brewery industry in Nigeria.

Table 5: Correlation Matrix of Leadership and Employee Commitment

\begin{tabular}{lllllll}
\hline & Mean & SD & 1 & 2 & 3 & 4 \\
\hline Transformational Leadership & 3.19 & .616 & 1 & & & \\
Transactional Leadership & 2.20 & .765 & $.269^{* *}$ & 1 & & \\
Laisses-faire Leadership & 1.29 & 1.406 & .077 & $.726^{* *}$ & 1 & \\
Employee commitment & 3.91 & .695 & $.178^{* *}$ & .101 & .030 & 1 \\
\hline
\end{tabular}

\section{** Correlation is significant at the 0.01 level (2-tailed). $\mathrm{N}=\mathbf{2 2 2}$ Source: Field Survey, 2019}

Table 5 shows inter-correlations among the three leadership styles and employee commitment. As shown in Table 5, the mean values for the transactional and laisses-faire leadership styles are relatively low compare to transformational leadership style. Employee commitment is relatively higher. Precisely, the dimensions of leadership styles exhibited low to moderate and high positive relationship with one another. From Table 4, transformational leadership and employee commitment $\left(\mathrm{r}=.178^{* *}, \mathrm{p}<0.01\right)$, Transactional leadership and employee commitment $(r=.101, p>0.01)$ and Laissez-faire leadership and employee commitment $(r=$ $.030, \mathrm{p}>0.01)$. From the above results, transformational leadership exhibits low positive and significant relationship with employee commitment. Both transactional and laissez-faire leadership styles exhibit low positive and non-significant relationship with employee commitment. Hierarchical multiple regression analysis was further carried out.

Table 6: Results of the hierarchical multiple regression with step 1 (predictors predicting employee commitment)

\begin{tabular}{lllllll}
\hline \hline Source & B & SE & B & T & P & $\begin{array}{l}\text { Significant } \\
\text { predictor }\end{array}$ \\
\hline \hline Gender & & & & & No & No \\
Age & -.011 & .098 & -.007 & -.113 & .910 & No \\
Years of experience on the job & .080 & .068 & .083 & 1.189 & .236 & Yes \\
Cadre of employee & -.001 & .041 & -.002 & -.026 & .979 & No \\
Educational qualification & .659 & .099 & .417 & 6.644 & .000 & .502 \\
\hline \hline
\end{tabular}

Results for the first block of the hierarchical regression are presented in Table 6. The first step (block 1) of the hierarchical multiple regression revealed that among the demographic factors investigated: gender, age, years of experience on the job, cadre of employee and educational qualification, only cadre of employee is a significant predictor of employee commitment $(\beta=.417$, $\mathrm{t}=6.644$ and $\mathrm{p}<.001$ ), others were not significant predictors of employee commitment. The first model revealed the following statistics $\mathrm{F}(5,216)=9.698, \mathrm{p}=.000, \mathrm{R}=.428, \mathrm{R}^{2}=.183$ and adjusted $\mathrm{R}^{2}=.164$. Results for step 2 of the hierarchical regression are presented in Table 7. In the second step (block 2) of the hierarchical multiple regression that included all of the predictor variables revealed that the combination of the control variables and the three leadership styles do significantly predict employee commitment, $\mathrm{F}(3,213)=1.381, \mathrm{p}>.001$.

Table 7: Results of the hierarchical multiple regression with step 2 (control variables and predictors predicting employee commitment)

\begin{tabular}{lllllll}
\hline \hline Source & B & SE & B & T & P & $\begin{array}{l}\text { Significant } \\
\text { predictor }\end{array}$ \\
\hline \hline Gender & & & & & No & No \\
Age & -.011 & .098 & -.007 & -.109 & .913 & No \\
Years of experience on the job & .095 & .068 & .098 & 1.387 & .167 & Yes \\
Cadre of employee & -.006 & .041 & -.010 & -.135 & .893 & No \\
Educational qualification & .786 & .124 & .498 & 6.340 & .000 & No \\
Transformational leadership & -.013 & .029 & -.030 & -.459 & .646 & No \\
Transactional leadership & -.100 & .085 & -.088 & -1.172 & .242 & No \\
Laissez-faire leadership & .014 & .088 & .015 & .153 & .878 & -170 \\
\hline \hline
\end{tabular}

From Table 7 above, the entire group of variables do not significantly predict employee commitment $\mathrm{F}(8,213)=6.611$, $\mathrm{p}=.249$ which is $>.001, \mathrm{R}=.446, \mathrm{R}^{2}=.199$, adjusted $\mathrm{R}^{2}=.169$. From the above statistics, the entire variables predicted $20 \%$ of employee commitment. The coefficient of determination $\left(\mathrm{R}^{2}\right)$ indicated that $20 \%$ of the variation in employee commitment can be explained 


\section{An Empirical Study of Leadership and Non-Financial Business Performance of Brewery Industry in Nigeria}

by leadership consisting of transformational, transactional and laissez-faire leadership styles. Model 2 of the hierarchical multiple regression analysis revealed that leadership influence employee commitment, but it is not a significant predictor of employee commitment. The outcome of this study contradicts the research carried out by Arjun and Ajaya (2014) and Ozge, Sabiha, and Engin (2015) who stated that leadership significantly predicted employee commitment.

Ho3: There is no statistical association between leadership style and turnover intention in the brewery industry in Nigeria.

Table 8: Correlation Matrix of leadership and turnover intention

\begin{tabular}{lllllll}
\hline & Mean & SD & 1 & 2 & 3 & 4 \\
\hline Transformational Leadership & 3.19 & .616 & 1 & & & \\
Transactional Leadership & 2.20 & .765 & $.269 * *$ & 1 & & \\
Laisses-faire Leadership & 1.29 & 1.406 & .077 & $.726^{* *}$ & 1 & \\
Turnover intention & 3.26 & .527 & $-.137^{*}$ & $.151^{*}$ & $.200^{* *}$ & 1 \\
\hline
\end{tabular}

\section{Source: Field Survey, 2019}

Table 8 shows inter-correlations among the three leadership styles and employee turnover intention. As shown in Table 8, the mean values for the transactional and laisses-faire leadership styles are relatively low compare to transformational leadership style. Specifically, the dimensions of leadership styles exhibited low to moderate and high positive relationship with one another. Table 8 depicts the relationship among the three leadership styles and employee turnover intention. Transformational leadership and turnover intention $\left(\mathrm{r}=-.137^{*}, \mathrm{p}<0.01\right)$, Transactional leadership and turnover intention $\left(\mathrm{r}=.151^{*}, \mathrm{p}<0.01\right)$ and Laissez-faire leadership and turnover intention $\left(\mathrm{r}=.200^{* *}, \mathrm{p}<0.01\right)$. From the above results, transformational leadership exhibits low negative and significant relationship with employee turnover intention. Also both transactional and laissez-faire leadership styles exhibit low positive and significant relationship with employee turnover intention. Subsequently, hierarchical regression was run.

Table 9: Results of the hierarchical multiple regression with step 1 (predictors predicting employee turnover intention)

\begin{tabular}{|c|c|c|c|c|c|c|}
\hline Source & בB & SE & 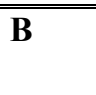 & $\bar{T} \mathbf{T}$ & $\overline{\mathbf{P}}$ & $\begin{array}{l}\text { Significant } \\
\text { predictor }\end{array}$ \\
\hline Gender & -.001 & 2.080 & -.001 & -.012 & 9990 & No \\
\hline Age & -.154 & .055 & -.209 & -2.791 & .006 & Yes \\
\hline Years of experience on the job & .101 & .033 & .229 & 3.008 & .003 & Yes \\
\hline Cadre of employee & .044 & .081 & .037 & .550 & .583 & No \\
\hline Educational qualification & .025 & .023 & .073 & 1.063 & .289 & No \\
\hline
\end{tabular}

Results for the first block of the hierarchical regression are presented in Table 9.The first step (block 1) of the hierarchical multiple regression revealed that among the demographic factors investigated: gender, age, years of experience on the job, cadre of employee, and educational qualification, only age $(\beta=-.209, \mathrm{t}=-2.791$ and $\mathrm{p}<.001)$ and years of experience on the job $(\beta=.229$, $\mathrm{t}=3.008$ and $\mathrm{p}<.001)$ are significant predictor of employee turnover intention, others were not significant predictors of turnover intention. The first model revealed the following statistics $\mathrm{F}(5,216)=2.562, \mathrm{p}=.028, \mathrm{R}=.237, \mathrm{R}^{2}=.056$ and adjusted $\mathrm{R}^{2}=.034$. Results for step 2 of the hierarchical regression are presented in Table 10. In the second step (block 2) of the hierarchical regression that included all of the predictor variables revealed that the combination of the control variables and the three leadership styles do significantly predict employee turnover intention, $\mathrm{F}(3,213)=3.999, \mathrm{p}<.001$.

Table 10: Results of the hierarchical multiple regression with step 2 (control variables and predictors predicting employee commitment)

\begin{tabular}{lllllll}
\hline Source & B & SE & B & T & p & $\begin{array}{l}\text { Significant } \\
\text { predictor }\end{array}$ \\
\hline \hline Gender & & & & & $\begin{array}{l}\text { No } \\
\text { Yes }\end{array}$ \\
Age & -.003 & .078 & -.002 & -.036 & .971 & Yes \\
Years of experience on the job & -.133 & .054 & -.182 & 2.473 & .014 & No \\
Cadre of employee & .114 & .033 & .259 & 3.495 & .001 & No \\
Educational qualification & .085 & .098 & .071 & .868 & .386 & Yes \\
Transformational leadership & .022 & .023 & .066 & .978 & .329 & No \\
Transactional leadership & -.100 & .067 & -.223 & -2.840 & .005 & No \\
Laissez-faire leadership & .014 & .070 & .076 & .757 & .450 & .130 \\
\hline \hline
\end{tabular}

From Table 10 above, the entire group of variables significantly predicted employee turnover intention $\mathrm{F}(8,213)=6.091$, $\mathrm{p}=.001$ which is $<.001, \mathrm{R}=.361, \mathrm{R}^{2}=.131$, adjusted $\mathrm{R}^{2}=.098$. From the above statistics, the entire variables predicted $13 \%$ of employee turnover intention. The coefficient of determination $\left(\mathrm{R}^{2}\right)$ indicated that $13 \%$ of the variation in employee turnover intention can be explained by leadership consisting of transformational, transactional and laissez-faire leadership. Model 2 of the hierarchical multiple regression analysis revealed that leadership consisted of transformational, transactional and laissez-faire leadership 


\section{An Empirical Study of Leadership and Non-Financial Business Performance of Brewery Industry in Nigeria}

influence employee turnover intention. Findings of this study demonstrated that leadership predicts employee turnover intention, which corroborated outcomes of studies carried out by Belete (2018) and Ebrahim (2018).

\section{CONCLUSION AND IMPLICATIONS}

This study investigated leadership and non-financial business performance at Nigerian Breweries Industry Plc. Leadership was evaluated using transformational, transactional and laisses-faire leadership styles. Non-financial business performance was measured using job satisfaction, employee commitment and turnover intention. Leadership is vital because successful leaders will be able to offer guidance and monitor subordinates achievement towards improved performance. The quality of leadership is very fundamental to employee and firm's performance (Spector, 2011; Mallikarjuna, 2014; Sid, 2018). Concerns for improve business performance as a way of improving firm success has enlarged among business leaders. This is because companies depend on effective leadership to motivate, inspire and sustain performance improvement (Van Wart, 2014). According to Leavy (2016), irrespective of the nature and scope of business, leadership role is a serious concern for the success of organizations. Therefore, to enhance employee satisfaction and job commitment, it is important for leaders to adopt effective leadership style to lessen employee stress and foster employee engagement (Burns, 2003). This is based on the premises that when a leader fails in promoting and nurturing job satisfaction, it become difficult to encourage desire behavior on the part of the employee and by extension it will create complications in accomplishing the firm's goals (Long et al., 2014).

Employee retention is a very vital issue if organizations are to accomplish and maintain success, therefore, leadership must develop and adopt effective leadership style to lessen turnover intention. Poor leadership style builds a toxic workplace where it will be challenging for subordinates to perform their job effectively resulting to declining job satisfaction, lack of commitment and intention to quit. David (2014) said that ineffective leadership results to loss of hope and create tension in the workplace, because employees will not be inspired and loss confidence working with the organization. Nowadays, competent leadership is in high demand in diverse business organizations and a great dexterity of leadership is prerequisite by the leaders to manage business organization (Salleh \& Grunewald, 2013). According to Lok and Crawford (2004), the success and failure of a firm are determined by the styles and practices demonstrated by the leaders. Dalluay and Jalagat (2016) remarked that leadership is an influencing factor towards promoting a thriving workplace where employees at all levels will be satisfied and committed to the goals of the organization. The dominant implication of this research study is that, leadership should take some innovative steps to improve employee's job satisfaction, enlarge employee commitment and lessens employee turnover intentions. Therefore, research into leadership and non-financial performance in the Nigeria brewery industry, may uncover the need for leadership development initiatives require to improve the performance of the industry. Also, findings of this research are important to researchers, business leaders and practitioners, as the conclusions drawn from this study may help them to recognize leadership style that are appropriate to drive both employee and company performance.

\subsection{Limitations and Suggestion for Further Studies}

All research studies have some essential limitations, irrespective of methodology (Yin, 2014). This study was limited in scope and generalizability, as the study participants were drawn from the Nigerian breweries industry Plc. Thus, participant viewpoints concerning leadership and non-financial performance may not account for overall perceptions of the population of employees in other breweries company or business settings. Future researchers could broaden the scope of the study by extending the investigation to other breweries companies and attempt to obtain larger sample size to produce more exciting findings. Besides, the study was correlational research, and is therefore not possible to prove causality. Future researchers could adopt other research design and introduce additional variables such organizational climate and reward management system as a mediating variables to enhance the generalizability of the findings.

\section{REFERENCES}

1) Abayomi, A. (2020). A quantitative study of leadership and performance of Brewery Industry in Nigeria. Unpublished Doctoral Thesis in Leadership and Change Management. Walden Dissertations and doctoral studies. Walden University.

2) Abbasi, S.M., Hollman, K.W., \& Hayes, R.D. (2008). Bad bosses and how not to be one. Information Management Journal, 42(1), 52-56.

3) Abdul, B., Veronica, S., \& Zubair, H. (2017). Impact of leadership styles on employee performance: A case study on private organization in Malaysia. International Journal of Accounting and Business Management, 5(2), 112-130. doi: 24924/ijbm/2017.11/v5.iss2/11

4) Allen, N.J., \& Meyer, J.P. (1990). The measurement and antecedents of affective, continuance, and normative commitment to the organization. Journal of Occupational Psychology, 63(1), 1-18. doi:10.1111/j.2044-83251990.tb00506x.

5) Arjun, K.S., \& Ajaya, K.M. (2014). Leadership styles, employees' commitment to organizational change, and organizational performance: A study in a Nepali technology based organization. 1-9. Paper presented at the 11th South Asian Management Forum (SAMF) organized by Association of Management Development Institutions in South Asia (AMDISA). 


\section{An Empirical Study of Leadership and Non-Financial Business Performance of Brewery Industry in Nigeria}

6) Babatunde, O. (2015). The impact of leadership style on employee's performance in an organization. IISTE, 5(1), 193206.

7) Bass, B., \& Bass, R. (2008). The Bass handbook of leadership: Theory, research and managerial application. New York: Simon \& Schuster.

8) Bass, B.M., \& Avolio, B. (1994). Improving organizational effectiveness through transformational leadership. Thousand Oaks, CA: Sage Publications.

9) Belete, A.K. (2018). Turnover intention influencing factors of employees: An empirical work review. Journal of Entrepreneurial Organization Management, 7(3), 1-7.

10) Bothma, F.C., \& Roodt, G. (2013). The validation of the turnover intention scale. South Africa Journal of Human Resource Management, 11(1), 507-519. doi:10.4102/sajhrm. v11i1.507.

11) Brockner, J., Tyler, T., \& Scheneider, T. (1992). The influence of prior commitment to an institution on reactions to perceived unfairness: The higher they are, the harder they fall. Administrative Science Quarterly, 37, 241-2615.

12) Burns, J. M. (2003). Transforming leadership: A new pursuit of happiness. NY: Atlantic Monthly Press.

13) Burns, J.M. (1978). Leadership. New York, NY: Harper \& Row.

14) Dahie, A.M., Mohamed, A.A., \& Mohamed, R.A. (2017). Leadership style and organizational commitment: Case study from University of Somalia. International Journal of Engineering Science and Computing, 7, 14838-14843.

15) Dalluay, D.V.S., \& Jalagat, D.R.C. (2016). Impacts of leadership style effectiveness of managers and department heads to employees' job satisfaction and performance on selected small-scale businesses in Cavite, Philippines. International Journal of Recent Advances in Organizational Behavior and Decision Sciences, 2(2), 734-751.

16) David, R.K. (2014). Leading from within: Building organizational leadership capacity. Retrieved from https://www.iedconline.org/clientuploads/Downloads/edrp/Leading_from_Within.pdf

17) Ebrahim, H.A. (2018). Impact of leadership styles on organizational performance. Journal of Human Resources Management Research, 2018, 1-10.

18) Eskildsen, J., \& Dahlgaard, J. (2000). A causal model for employee satisfaction. Total Quality Management, 11(8), 10811094. doi: $10.1080 / 095441200440340$

19) Fry, L.W. (2003). Toward a theory of spiritual leadership. The leadership Quarterly, 14(6), 693-727

20) Fu, F.Q., Bolander, W., \& Jones, E. (2009). Managing the drivers of organizational commitment and salesperson effort: An application of Meyer and Allen's three component model. The Journal of Marketing Theory and Practice, 17(4), 335350. doi:10.2753/mtp1069-6679170403

21) Furnham, A., Eracleou, A., \& Chamorro-Premuzic, T. (2009). Personality, motivation and job satisfaction: Hertzberg meets the Big Five. Journal of Managerial Psychology, 24(8), 765-779.

22) Garg, A.K., \& Ramjee, D. (2013). The relationship between leadership styles and employee commitment at a parastatal company in South Africa. International Business and Economics Research Journal, 12, 1411-1436.

23) Gcaza, N., Garande, B., \& Echezona, N.E. (2018). The effects of leadership style and organizational culture on employees' organizational commitment. Journal of Social Science, 54( (1- 3), 31-41.

24) Gill, R. (2012). Theory and practice of leadership. Thousand Oaks, CA: Sage.

25) Goodnight, R. (2011). Laissez-faire leadership. In G. R. Goethals, G. J. Sorenson, \& J. MacGregor Burns (Eds.), Encyclopedia of leadership. London, England: Sage. doi:10.4135/9781412952392.n189

26) Haque, A., Faizan, R., \& Cockrill, A. (2017). The relationship between female representation at strategic level and firm's competitiveness: evidences from cargo logistic firms of Pakistan and Canada. Polish Journal of Management Studies, 15(2), 69-81. doi:10.17512/pjms.2017.15.2.07

27) Harms, P., \& Crede, M. (2010). Emotional intelligence and transformational and transactional leadership: A metaanalysis. Journal of Leadership \& Organizational Studies, 17(1), 5-17. doi:10.1177/1548051809350894

28) Haukur, G. (2017). The current situation and future prospects of beer export from Iceland. MSc International Business \& Marketing. Haskelinn Reykjavik University. Retrieved from https://skemman.is/bitstream/1946/28650/1/MIB\%26M0617_Thesis_Haukur.

29) Jing, F.F., \& Avery, G.C. (2008). Missing Links in Understanding the relationship between leadership and organizational performance. International Business \& Economics Research Journal, 7(5), 67-78.

30) Kirkbride, P. (2006). Developing transformational leaders: The Full Range Leadership Model in action. Industrial and Commercial Training, 38(1), 23-32.

31) Leavy, B. (2016). Effective leadership today-character not just competence. Strategy \& Leadership, 44(1), 20-29. doi:10.1108/SL-11-2015-0081

32) Lee, S.H., \& Ha-Brookshire, J. (2017). Ethical climate and job attitude in fashion retail employees' turnover intention, and perceived organizational sustainability performance: A cross-sectional study. Sustainability, 9, 465. 


\section{An Empirical Study of Leadership and Non-Financial Business Performance of Brewery Industry in Nigeria}

33) Lok, P., \& Crawford, J. (2004). The effect of organizational culture and leadership style on job satisfaction and organizational commitment: A cross-national comparison. Journal of Management Development, 23(4), 321-338.

34) Long, C.S., Yusof, W.M., Kowang, T.O., \& Heng, L.H. (2014). The impact of transformational leadership style on job satisfaction, World Applied Sciences Journal, 29(1), 117-124

35) Loquercio, D., Hamersley, M., \& Emmens, B. (2006). Understanding and addressing staff turnover in humanitarian agencies. Oversees Development Institute: The Humanitarian Practice Network.

https://www.files.ethz.ch/isn/93897/networkpaper055.pdf

36) Mallikarjuna, N.L. (2014). Impact of personal management practices on managerial commitment in Small Scale Industries in Mysore District. IJMDRR, 1(9), 182-186.

37) Mat, J. (2008). The influence of leadership style on internal marketing in retailing. Unpublished PhD Thesis. University of Stirling.

38) Meristem Securities (2014). Breweries sector report. Retrieved from http://www.meristem.com.ng/uploads/files/2014\%20Breweries\%20Sector\%20report.pdf

39) Meyer, J.P., \& Allen, N.J. (1991). A three-component conceptualization of organizational commitment. Human Resource Management Review, 1, 61- 89. doi:10.1016/1053-4822(91)90011-Z

40) Miles, S.J., \& Mangold, G. (2002). The impact of team leader performance on team members' satisfaction: the subordinate's perspective. Team Performance Management: An International Journal, 8 (5/6), pp. 113-121.

41) Mosadeghrad, A.M. (2003). Principles of health care administration. Tehran: DibagranTehran.

42) Motowidlo, S.J., \& Kell, H.J. (2012). Chapter 5 job performance. Handbook of Psychology. doi.org/10.1002/0471264385.wei1203

43) Mujkic, A., Sehic, D., Rahimic, Z., \& Jusic, J. (2014). Transformational leadership and employee satisfaction. Review of Contemporary Business, Entrepreneurship and Economic, 27, 259-270.

44) Newhaul, S. (2012). Preparing our leaders for the future. Strategic HR Review, 11(1), 5- 12. doi: $10.1108 / 14754391211186250$

45) Ni-Nengah, R. K., Wayan, S., \& Nengah, S. (2018). The effect of leadership style to job satisfaction, employee engagement and employee performance: Study at PT. Interbat, Bali, Nusra, and Ambon. International Journal of Contemporary Research and Review, 9(3), 20592-20600. doi:10.15520/ijcrr/2018/9/03/468

46) Northouse, P.G. (2016). Leadership theory and practice (7th ed.) Thousand Oaks, CA: Sage Publications.

47) Ozge, O., Sabiha, I., \& Engin, K. (2015). The effect of leadership on organizational commitment. Leadership and Organizational Outcomes, pp. 57-79. doi:10.1007/978-3-319-14908-0_4

48) Park, J.E., \& Deitz, G.D. (2006). The effect of working relationship quality on salesperson performance and job satisfaction: Adaptive selling behavior in Korean Automobile Sales Representative. Journal of Business Research, 59(2), 204-213

49)Phuong, T.H. (2016). The moderating impacts of age and locus of control on the psychological contract breach-outcomes relationships: A Vietnam-Japan comparative study. International Journal of Business and Society, 17(2), 329-346.

50) Rahim, A.G., Ofuani, A.B., \& Olonode, O.P. (2018). Trends in business performance measurement: A literature analysis International Journal of Social Sciences and Humanities Reviews, 8(1), 151160.

51) Rahman, W., \& Nas, Z. (2013). Employee development and turnover intention: theory validation. European Journal of Training and Development, 37(6), 564-579.

52) Raja, A.S., \& Palanichamy, P. (2011). Leadership styles and its impact on organizational commitment. The Journal of Commerce, 3(4), 15-23.

53) Robbins, S. (2006). Organizational behavior. New Jersey: Prentice Hall.

54) Robbins, S., \& Judge, T.A. (2017). Organizational behavior. (13th eds.). Essex: Pearson Education Limited.

55) Salleh, M., \& Grunewald, D. (2013). Organizational leadership-The strategic role of the Chief Executive. Journal of Leadership, Accountability, and Ethics, 10(5), 9-20.

56) Schepers, J., Wetzels, M., \& Ruyter, K.D. (2005). Leadership styles in technology acceptance: Do followers practice what leaders preach? Managing Service Quality, 15(6), 496-508.

57) Shahzad, N.S.1., \& Khanzada, B. (2018). Role of transformational leadership in employee's performance with mediating role of job satisfaction in Health Sector of Pakistan. Journal of Health Education Research Development, 6(1), 7.

58) Sid, T. (2018). Managerial turnover intention as a result of leadership behavior, job satisfaction and organizational commitment: evidence from cross-national fitness enterprises in Thailand. Academy of Strategic Management Journal, $17(1), 1$.

59) Siew, K. (2017). Analysis of the relationship between leadership styles and turnover intention within Small Medium Enterprise in Malaysia. Arts Social Science Journal, 1, 1-11.

60) Spector, P.E. (2011). Job satisfaction survey. Retrieved from http://chuma.cas.usf.edu 


\section{An Empirical Study of Leadership and Non-Financial Business Performance of Brewery Industry in Nigeria}

61) Tnay, E., Othman, A.E., Siong, H.C., \& Omar, S.L. (2013). The influences of job satisfaction and organizational commitment on turnover intention. Procedia-Social and Behavioral Sciences, 97, 201-208. doi:10.1016/j.sbspro.2013.10.223

62) Trottier, T., Van Wart, M., \& Wang, X. (2008). Examining the nature and significance of leadership in government organizations. Public Administration Review, 2008, 319-333.

63) Tse, H.M., \& Lam, W. (2008). Transformational leadership and turnover: The roles of LMX and organizational commitment. Academy of Management Annual Meeting proceedings, pp. 1-6. Retrieved from http://aom.pace.edu/proceedings/2008/AOM2008/.pdf.

64) Ugboro, I.O. (2006). Organizational commitment, job redesign, employee empowerment and intent to quit among survivors of restructuring and downsizing. North Carolina Institute of Behavioral and Applied Management. Retrieved from http://www.ibam.com/pubs.pdf.

65) Van Wart, M. (2014). Leadership in public organizations: An introduction. London: Routledge.

66) Vandenberghe, C. (2014). Affective commitment to organizations and supervisors and turnover: A role theory perspective. Journal of Management, 43(7), 2090-2117. doi:10.1177/0149206314559779

67) Wang, X., Wang, L., Xu, X., \& Ji, P. (2014). Identifying employee turnover risks using modified quality function deployment. Systems Research and Behavioral Science, 31(3), 398-404. doi:10.1002/sres.2282

68) Yahchouchi, G. (2009). Employees' perceptions of Lebanese managers' leadership styles and organizational commitment. International Journal of Leadership Studies, 4, 127-140.

69) Yamane, T. (1967). Statistics: An introductory analysis (2nd eds.). New York: Harper and Row.

70) Yasir, M., Imran, R., Irshad, M.K., Mohamad, N.A., \& Khan, M.M. (2016). Leadership styles in relation to employees' trust and organizational change capacity: Evidence from non-profit organisations. SAGE Open, 6(4), 5. doi:10.1177/2158244016675396

71) Yin, R.K. (2014). Case study research: Design and methods (5th eds.). Thousand Oaks, CA: Sage. doi:10.4135/9781473915480.n38 